\title{
An Approach for Mapping and Management Strategies of Waterlogged Areas using Geo-spatial Technique
}

\author{
Kalpana Paudyal ${ }^{1}$, R.K. Jhorar ${ }^{2}$, K.E. Mothi Kumar ${ }^{3}$ \\ 1,2Chaudhary Charan Singh Haryana Agricultural University, Hisar, Haryana, India \\ 3 Haryana Space Applications Centre, Hisar, Haryana, India \\ Email: 1kalpu_gemini89@yahoo.co.in
}

Abstract

Waterlogging is one of the major problem of land degradation processes. Reliable and accurate mapping of areas affected by these processes with their location and extent can be extremely useful in chalking out suitable water management strategies and also to undertake remedial measures to prevent their advancement. The study was carried out for Rohtak district of Haryana, India. For this study IRS - 1D, LISS-III satellite data acquired on March 6, 2010 was used to identify surface water logged area as well as to update different topographical features digitized with the help of SOI topo sheets. Water table depth and groundwater quality maps were also prepared using data collected from different sources. GIS environment was used to prepare and overlay different thematic maps and to extract the desired information. Based on satellite imagery, about one per cent of the study area was found to be affected by surface waterlogging during the pre-monsoon period of 2010 . Management strategies were suggested depending on the nature of the problem i.e. surface or sub-surface waterlogging as well as depth and quality of groundwater.

Keywords: Waterlogging, remote sensing, water table depth, groundwater quality, management strategies

\section{I.INTRODUCTION}

The first observation wells to monitor the effect of irrigation on the groundwater table depth were installed as early as in 1870 . Based on these studies, various remedial measures were tried. These measures included closure of canals in the monsoon season, construction of surface drains in waterlogged areas and lowering of full supply levels of canals [1]. Waterlogged area in IGNP Stage I was determined from IRS IA LISS I| FCC imageries. Attempt was also made to correlate the IRS$1 \mathrm{~A}$ derived waterlogged area with the available water depth and electrical conductivity data to assess the area sensitive to waterlogging [2].Surface waterlogging is the accumulation of surface runoff and thereby stagnation of water over depressed lands due to blockage of natural drainage and/or higher water level at the outfalls [3]. Waterlogging in the low lying areas is created due to seepage from irrigated uplands and seepage from canal water with inadequate water management practices. [4].

IRS data have been proved to be very successful for the assessment of waterlogging. Density slicing and principal component analyses are useful techniques in making an assessment of waterlogged areas in irrigated command areas [5]. Temporal IRS-IA-LISS-I FCC data for 1988 , was used to derive land use and drainage maps to delineate waterlogged areas and area sensitive to waterlogging in the Tawa command. [6]. Waterlogged areas with either standing water (surface ponding) or a thin film of water at the surface or the land with wet surface were detected, using Landsat (MSS and TM) and Indian Remote Sensing Satellite (IRS-1A/1B/1C/1D) Linear Imaging Self-scanning Sensor (LISS) data [7].

The principal approach for reducing water logging and inundation problems in dry land agriculture has involved engineering works to divert runoff into water storages (dams) and natural drainage lines and to lower perched water tables within the root zone using interceptor, relief, mole and slotted-pipe drains. [8]. RS and GIS can be used separately or in combination with hydrological models. With the aid of these techniques, it is possible to develop better regional model of hydrological processes in a drainage basin [9]. A highly advanced approach was presented for groundwater management and protection in Denmark. Their approach included spatially dense geophysical/hydrogeological mapping, dense perforation grids as well as numerical modelling, GIS and advanced database technology [10]. Multiple well point pumping/siphon system, cyclic use of canal water (CW) and poor quality groundwater, 
biodrainage and conventional drainage system are appropriate strategies for the management of waterlogged areas [11].

The study area chosen for present work is Rohtak district falling in southeastern part of Haryana (India) and lies between latitude $28^{\circ} 40^{\prime} 30^{\prime \prime}$ to $29^{\circ} 05^{\prime} 35^{\prime \prime} \mathrm{N}$ and longitude $76^{\circ} 13^{\prime} 22^{\prime \prime}$ to $76^{\circ} 51^{\prime} 20^{\prime \prime} \mathrm{E}$. It covers an area of about $1668 \mathrm{~km}^{2}$. The Rohtak district is sub-divided into 5 development blocks namely Kalanaur, Lakhan Majra, Meham, Rohtak and Sampla. The climate of Rohtak district can be classified as subtropical, semi-arid, continental and monsoon type. The annual rainfall varies considerably from year to year with an average of 458.5 $\mathrm{mm}$. The principal precipitation occurs during monsoon period from June to September when about $80 \%$ of the rainfall is received. Plain land and some undulating sandy dunes mark the overall topography of the district. There is a gentle slope from north to south and considerable slope from west to east. Jawaharlal Nehru feeder and Bhalaut sub branch are the two main canals running in the district with its sub branches, distributaries, minors and subminors.

\section{II.METHODOLOGY}

In the present study, remote sensing application software ERDAS IMAGINE 9.1 [12] was used to analyse satellite images. The GIS software Arc Map 9.3 [13] was used to prepare different maps of the study area. Survey of India Toposheet No. 53C $(4,8,12)$ and 53D $(1,5,9,13,6,10,14)$ on $1: 50,000$ scale (Surveyed during 1967-68) was used to delineate the study area. Different canals, drains, railway lines and roads were digitized to prepare the different thematic maps. The newly added features were updated with the help of satellite imagery.

Table 1. Specification of IRS - 1D, LISS-III satellite data

\begin{tabular}{|c|c|c|c|}
\hline $\begin{array}{c}\text { Spectral } \\
\text { Resolution }(\boldsymbol{\mu m})\end{array}$ & $\begin{array}{c}\text { Spatial } \\
\text { Resolution } \\
(\mathbf{m})\end{array}$ & $\begin{array}{c}\text { Path } \\
\text { No. }\end{array}$ & $\begin{array}{c}\text { Row } \\
\text { No. }\end{array}$ \\
\hline Band 1: $0.52-0.59$ & 23.5 & 95 & 50 \\
Band 2: $0.62-0.68$ & & 96 & 51 \\
Band 3: $0.77-0.86$ & & & \\
Band 4: $1.55-1.70$ & & \\
\hline
\end{tabular}

The block boundary map obtained from the Deputy Commissioner office were digitized and transferred to the thematic maps. IRS - 1D, LISS-III satellite data acquired on March 6, 2010 (Table 1) was used to delineate surface waterlogged area.

The False Colour Composite (FCC) [(Band-1,2,3)] of study area was prepared after mosaicing and georeferencing of satellite data and thereafter on screen digitisation of satellite data was done for delineation of surface waterlogged areas. Pixels having dark blue signatures were identified as surface waterlogged. Cluster of pixels showing presence of surface water (dark blue tone) but located near settlements and showing regular shape were considered as artificial water storage structures and not digitized as surface waterlogged. Groundwater depth data for June 2010 was used to prepare the depth of groundwater map. Data from a total of 98 No. of observation wells was available for the June, 2010 (Table 2).

Table 2. Blockwise number of observation wells for which depth of

groundwater was available during June, 2010

\begin{tabular}{|c|c|c|}
\hline Block & Area $\left.\mathbf{( k m}^{2}\right)$ & $\begin{array}{c}\text { No. of observation } \\
\text { wells }\end{array}$ \\
\hline Kalanaur & 295.59 & 18 \\
\hline Lakhan Majra & 132.47 & 11 \\
\hline Meham & 461.94 & 24 \\
\hline Rohtak & 534.75 & 32 \\
\hline Sampla & 247.99 & 13 \\
\hline Rohtak district & $\mathbf{1 6 7 2 . 7 4}$ & $\mathbf{9 8}$ \\
\hline
\end{tabular}

As per the norms used by the Groundwater Cell, water table map was prepared to categorize the water table depth as fully waterlogged (depth $<1.5 \mathrm{~m}$ ), waterlogged $(1.5-3 \mathrm{~m})$, potentially waterlogged $(3-10 \mathrm{~m})$ and safe $(>10 \mathrm{~m})$. The reduced levels of the study area were available at all the observation wells of the Groundwater Cell, Rohtak. The reduced level in the study area ranged from 214.5 to $223.5 \mathrm{~m}$. The groundwater quality data for the year 2010 was derived from AICRP report (2010-2011) on "Management of salt affected soils and use of saline water in agriculture". The total study area was divided into four different groundwater quality regions viz. good (0-2 dS $\left.\mathrm{m}^{-1}\right)$, marginally saline (2-4 dS $\left.\mathrm{m}^{-1}\right)$, saline $\left(4-8 \mathrm{dS} \mathrm{m}^{-1}\right)$ and highly saline $\left(>8 \mathrm{dS} \mathrm{m}^{-1}\right)$.

\section{A.Stratification of different thematic maps}

For the detailed analysis of study, various maps were stratified for different combination of the thematic maps. Different combinations were used during stratification such as surface waterlogging and canal 
network, surface waterlogging and drainage network, surface waterlogging and water table depth, surface waterlogging and topography, surface waterlogging and road network, groundwater quality (EC) and water table depth, water table depth and drainage network and water table depth and canal network.

\section{B.Identification of management strategies for waterlogged areas}

The management strategies were identified separately for surface and subsurface waterlogged areas. In order to identify suitable strategy for surface waterlogged areas, the extent of surface waterlogged areas was summarized based on its distance from canals, drains and roads. Management strategies for subsurface waterlogged areas were identified based on depth and quality of groundwater. Management options were considered by included surface drainage system, efficient irrigation system, reduction in canal water supply, conjunctive use of canal water, groundwater and rainwater, introduction of salt tolerant crops, plantation of highly transpiring trees, planned leaching of salts and fish farming with saline water.

\section{III.RESULTS AND DISCUSSION}

\section{A. Waterlogging in study area}

The surface waterlogged areas delineated for premonsoon period is shown in Fig.1. The block wise relevant statistics are given in Table 3

Table 3. Surface waterlogged area in Rohtak district for the pre monsoon period (March, 2010).

\begin{tabular}{|c|c|c|}
\hline Block & Area, $\mathbf{k m}^{\mathbf{2}}$ & \% of district area \\
\hline Kalanaur & 2.35 & 0.14 \\
\hline Lakhan Majra & 1.51 & 0.09 \\
\hline Meham & 4.03 & 0.24 \\
\hline Rohtak & 6.99 & 0.41 \\
\hline Sampla & 1.84 & 0.10 \\
\hline Rohtak district & $\mathbf{1 6 . 7 2}$ & $\mathbf{0 . 9 8}$ \\
\hline
\end{tabular}

The total surface waterlogged area in Rohtak district during March, 2010 was $16.72 \mathrm{~km}^{2}$ which comprises nearly $1 \%$ of the total area. The study area is faced with both surface and subsurface waterlogging problem. Presence of surface waterlogged area in the study area, even during pre-monsoon season, indicates the seriousness of the problem. The surface waterlogged area, in different blocks, as a percent of total area of respective blocks is shown in Fig. 2.

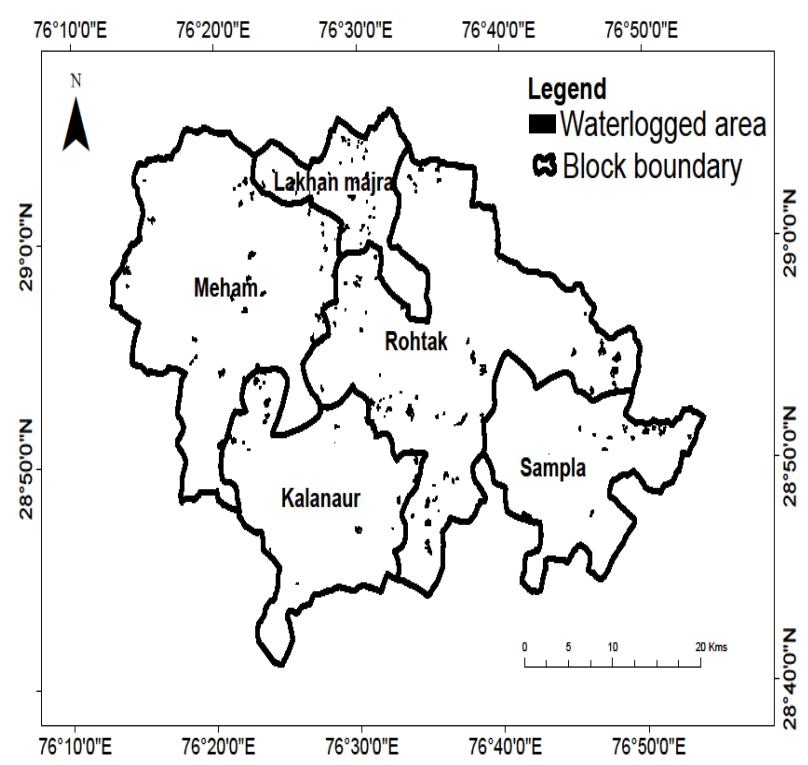

Figure. 1. Surface waterlogged area in Rohtak district as delineated using IRS 1D LISS-III satellite data, for premonsoon period in 2010

It is clear that the surface waterlogging problem was observed to be maximum in Rohtak block and minimum in Sampla block. Knowing that water absorbs most of the EM radiation, identification of surface waterlogged area on FCC shall not be very difficult, as the water pixels must show up dark blue signatures. However, during the course of image (FCC) inspection, it was observed that some of the area on FCC showed up as complex mixture of dark and reddish tone, darker tone being in relatively smaller proportion- such an area could be either surface waterlogged with active growth of aquatic vegetation or recently irrigated area with poor crop growth. Therefore, it was difficult to identify through visual inspection, the exact nature of areas on FCC which showed up as complex mixture of dark and reddish tone. Likewise some of the area on FCC showed up as of relatively light dark tone as compared to dark blue tone of water pixels. Again there may be two main possibilities for areas with relatively light dark tone - such an area could be either surface waterlogged with relatively smaller depth of surface water or recently irrigated/moist fields. Considering shallow water table in the study area it is very likely to have fields with moist conditions due to capillary rise. Presence of groundwater at shallow depth may also create waterlogging problems. 

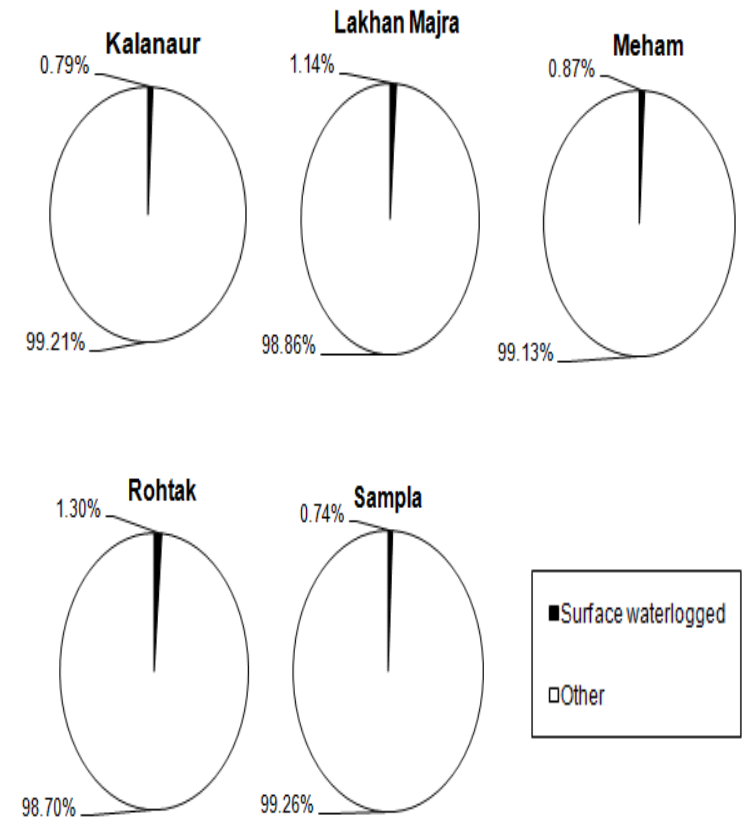

Figure. 2. Surface waterlogged area in different blocks of Rohtak district

Depth of ground water is a good indicator in case of waterlogged area. Water table depth map of June 2010 is shown in (Fig. 3). Block wise area under different water table depth is given in (Table 4). The fully waterlogged area (water table depth $<1.5 \mathrm{~m}$ ) is spread over $1.04 \%$ of the study area. It was maximum in Rohtak block and minimum in Lakhan Majra block. Likewise, $28.52 \%$ of study area may be categorized as waterlogged (water table depth 1.5 to $3 \mathrm{~m}$ ), $69.08 \%$ as potentially waterlogged (water table depth 3 to $10 \mathrm{~m}$ ) and $1.36 \%$ as safe (water table depth $>10 \mathrm{~m}$ ).

Table 4. Area $\left(\mathrm{km}^{2}\right)$ under different water table depth in Rohtak district (June-2010)

\begin{tabular}{|c|c|c|c|c|}
\hline Block & \multicolumn{4}{|c|}{ Depth $(\mathbf{m})$} \\
\hline Kalanaur & 3.58 & 49.61 & 242.40 & - \\
\hline Lakhan Majra & 0.33 & 55.82 & 71.07 & 5.26 \\
\hline Meham & - & 135.27 & 326.28 & 0.41 \\
\hline Rohtak & 10.27 & 187.63 & 319.62 & 17.24 \\
\hline Sampla & 2.66 & 48.82 & 196.50 & - \\
\hline $\begin{array}{c}\text { Rohtak } \\
\text { district }\end{array}$ & 16.84 & 477.15 & 1155.87 & 22.91 \\
\hline
\end{tabular}

Relative proportion of the study area under different water table depth is shown in Fig. 4. It is important to note that the area under different water table depth reported are pre monsoon period. In the post monsoon period the area under shallow water table depth is expected to increase. The shallow water table depth upto $3.0 \mathrm{~m}$ may be considered as of immediate concerns. The Lakhan Majra block has the highest proportion of area ( $>42 \%$ of its area) under shallow water table depth $<3.0 \mathrm{~m}$, among different blocks with majority of the area being in the water table depth range of 1.5 -3.0 m. Likewise for other blocks, most of area under shallow water table $(<3.0 \mathrm{~m})$ is in the water table depth range of $1.5-3.0 \mathrm{~m}$.

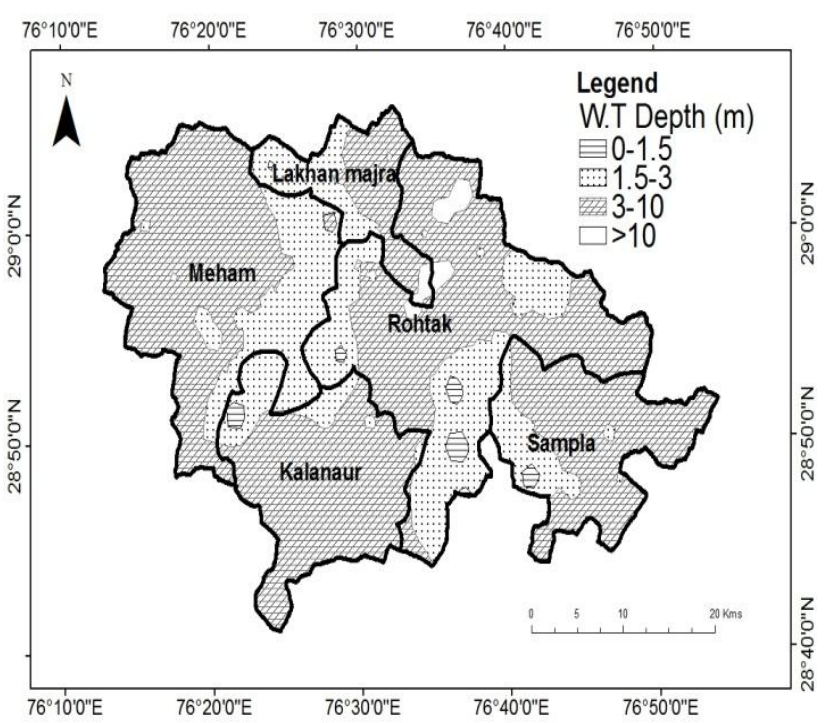

Figure. 3. Water table depth map of Rohtak district for June 2010.

It is interesting to note that the inspection of satellite imagery showed that $4.03 \mathrm{~km}^{2}$ area in Meham block was affected by surface waterlogging (Table 3 ). On the other hand, the water table depth map shows that water table is deeper than $1.5 \mathrm{~m}$ in whole of the Meham block. Although there was a gap of 3 months between the acquisition of satellite imagery (March 6, 2010) and the water table depth observation (June, 2010), it is surprising to note that water table is deeper than $1.5 \mathrm{~m}$ in whole of the Meham block.
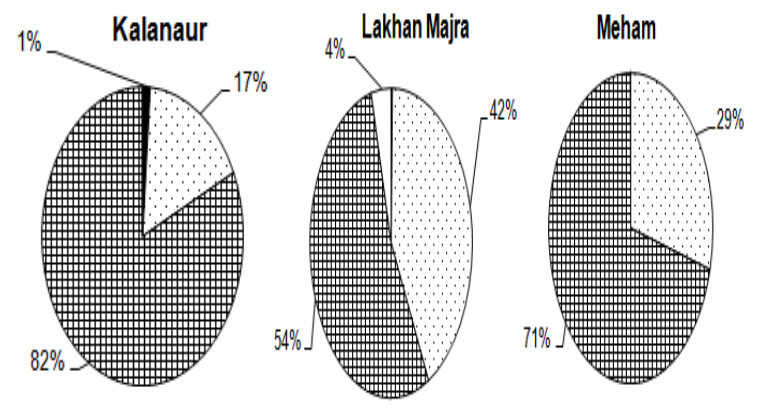

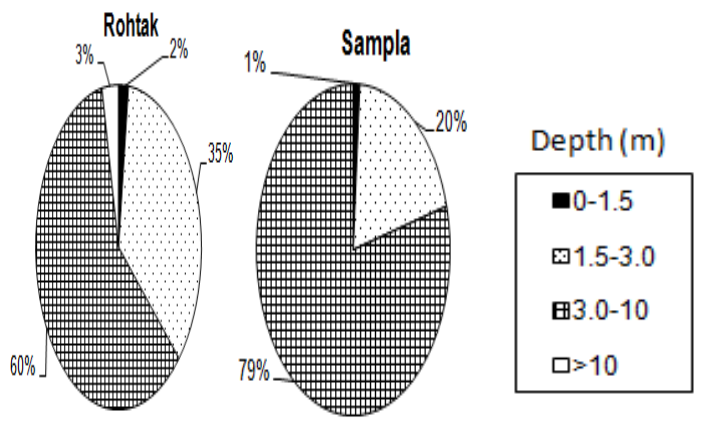

Figure. 4. Relative proportion of area under different water table depth in different blocks of Rohtak district

The surface waterlogged areas with respect to the water table depth are shown in Fig.5. The surface waterlogged area underlain with different water table depth is given in Table 5 .

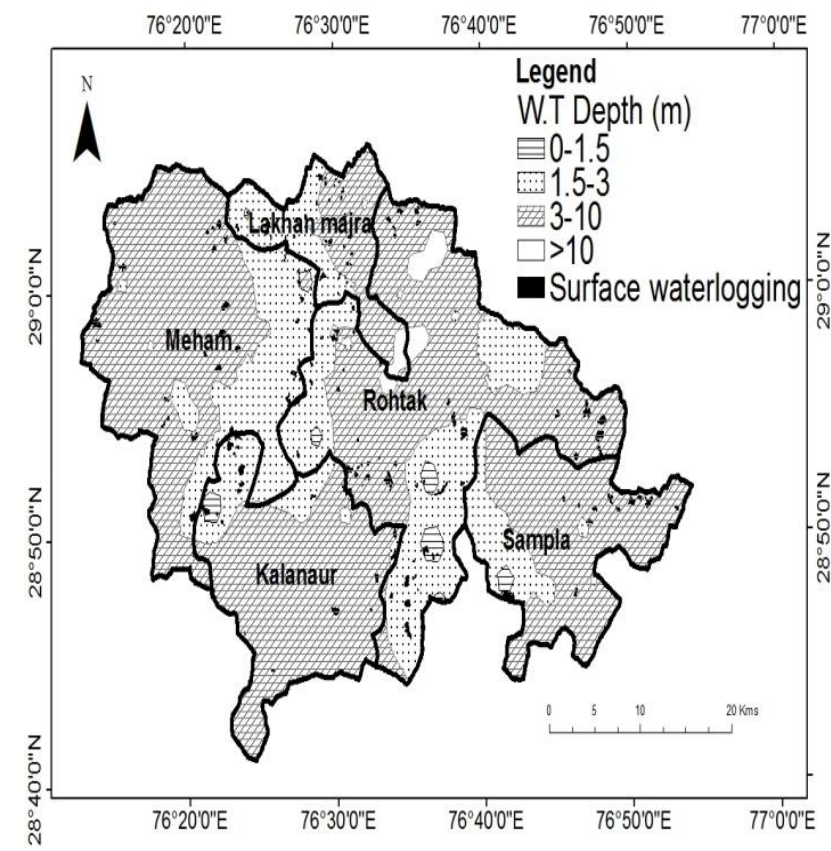

Figure. 5. Waterlogged area and water table depth of Rohtak district

The spatial distribution of surface waterlogged area with respect to water table depth is shown in Fig.5. It is clear that only a small fraction of surface waterlogged area in the Rohtak district is shown to be underlain with water table depth of less than $1.5 \mathrm{~m}$. Infact it is shown that majority of surface waterlogged area is underlain with water table depth of 3-10 m. Although it is not impossible to have such a situation e.g. surface water may accumulate in local depressions while water table could still be deeper at that location.
Table 5. Surface waterlogged area (ha) under different water table depth

\begin{tabular}{|c|c|c|c|c|c|}
\hline \multirow{2}{*}{ Block } & \multirow{2}{*}{$\begin{array}{c}\text { Surface } \\
\text { waterlogged } \\
\text { area }\end{array}$} & \multicolumn{4}{|c|}{$\begin{array}{c}\text { Surface waterlogged area } \\
\text { on different water table } \\
\text { depth (range) }\end{array}$} \\
\cline { 3 - 7 } & $0-1.5$ & $1.5-3$ & $3-10$ & $>10$ \\
\hline Kalanaur & 235 & 29.7 & 104.7 & 100.6 & - \\
\hline $\begin{array}{c}\text { Lakhan } \\
\text { Majra }\end{array}$ & 151 & - & 85.9 & 65.1 & - \\
\hline Meham & 403 & - & 143.1 & 259.9 & - \\
\hline Rohtak & 699 & 32.2 & 271.1 & 395.7 & - \\
\hline Sampla & 184 & 9.7 & 57.2 & 117.1 & - \\
\hline
\end{tabular}

Following two possibilities may be responsible for the conflicting situation of surface waterlogging vis a vis water table depth.

(a)The network of observation wells is not sufficient to capture the true picture of water table depth in the study area. It may also be possible that the observation wells located in the surface waterlogged area are not being monitored due to accessibility problems.

(b) The number of observation points for surface elevations for this study (which is same as number of observation wells) is also not sufficient to capture the true picture of topographical variation in the study area.

\section{B. Anthropic landscape modifications and waterlogging}

The surface waterlogged areas with respect to the canal network are shown in Fig. 7. The surface waterlogged area at different distance from the canals is given in Table 6.

Table 6. Surface waterlogged area (ha) as a function of distance from canals

\begin{tabular}{|c|c|c|c|c|}
\hline \multirow{2}{*}{ Block } & \multirow{2}{*}{$\begin{array}{c}\text { Surface } \\
\text { waterlogged } \\
\text { Area }\end{array}$} & \multicolumn{3}{|c|}{$\begin{array}{c}\text { Surface waterlogged } \\
\text { area within a distance } \\
\text { (from canal) of }\end{array}$} \\
\cline { 3 - 5 } & $\mathbf{2 0 0} \mathbf{~ m}$ & $\begin{array}{c}\mathbf{2 0 0}- \\
\mathbf{5 0 0} \mathbf{~ m}\end{array}$ & $\mathbf{> 5 0 0} \mathbf{~ m}$ \\
\hline Kalanaur & 235 & 10 & 12 & 213 \\
\hline $\begin{array}{c}\text { Lakhan } \\
\text { Majra }\end{array}$ & 151 & 30 & 34 & 87 \\
\hline Meham & 403 & 137 & 101 & 165 \\
\hline Rohtak & 699 & 115 & 83 & 501 \\
\hline Sampla & 184 & 19 & 19 & 146 \\
\hline
\end{tabular}




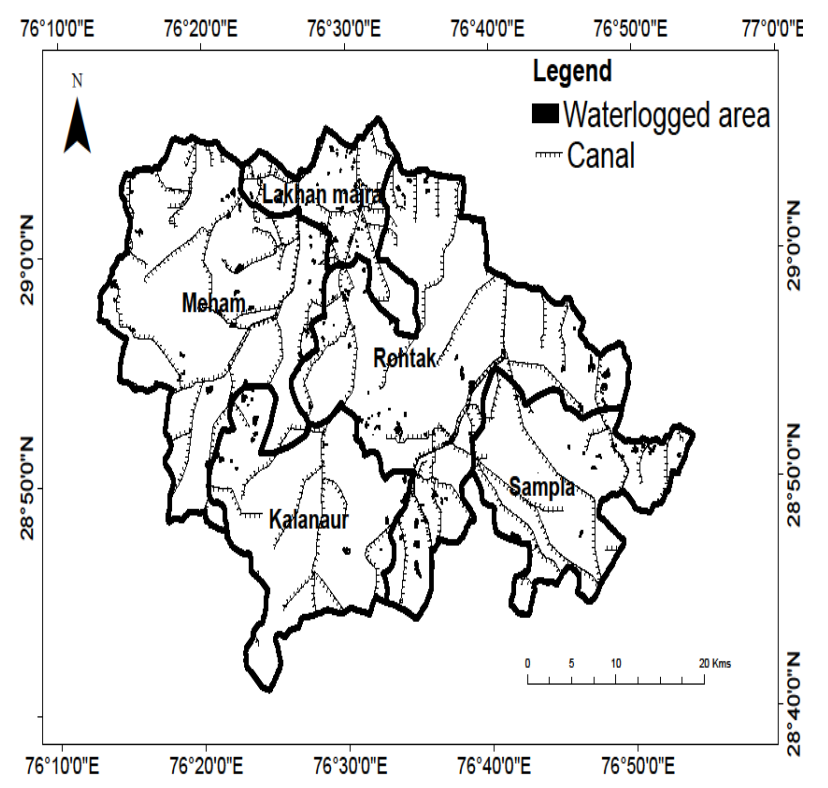

Figure. 7. Surface waterlogged area with respect to canal network in the study area
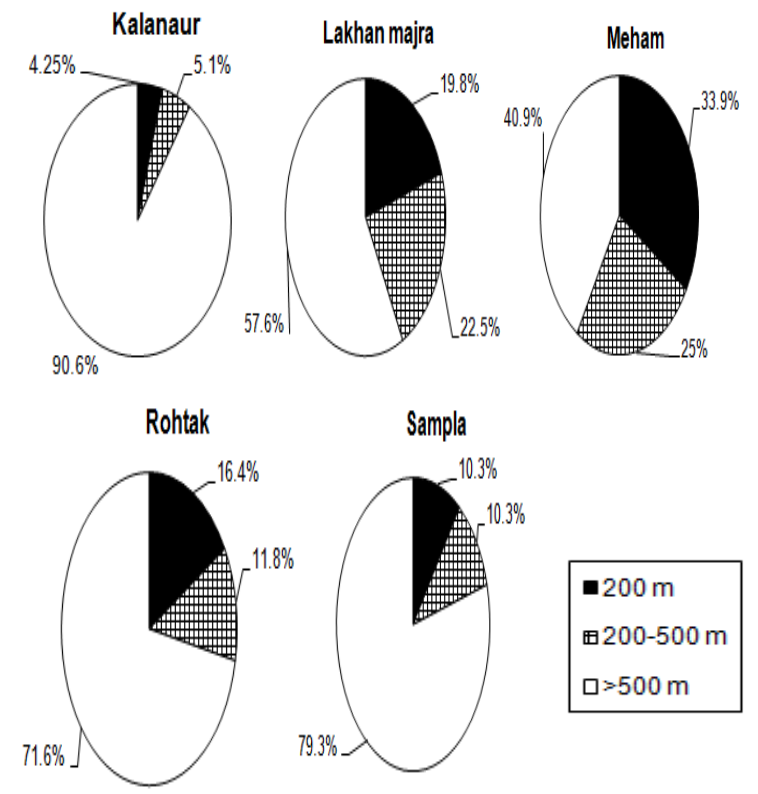

Figure. 8. Surface waterlogged area at different distances from canals in different blocks of Rohtak district

If the direct losses (e.g. spills) from canal irrigation system are considerable, one would expect maximum surface waterlogged are near canals. Except for Meham and Lakhan Majra block, majority of surface waterlogged area is located at distance greater than $500 \mathrm{~m}$ from the canals (Fig. 8). For instance, only about 9, 42, 59, 28 and 20 percent of the surface waterlogged area in Kalanaur, Lakhan Majra, Meham, Rohtak and Sampla block, respectively, was located within a distance of $500 \mathrm{~m}$ from the canals. Seepage from canals may cause water table to rise in the vicinity of canals.

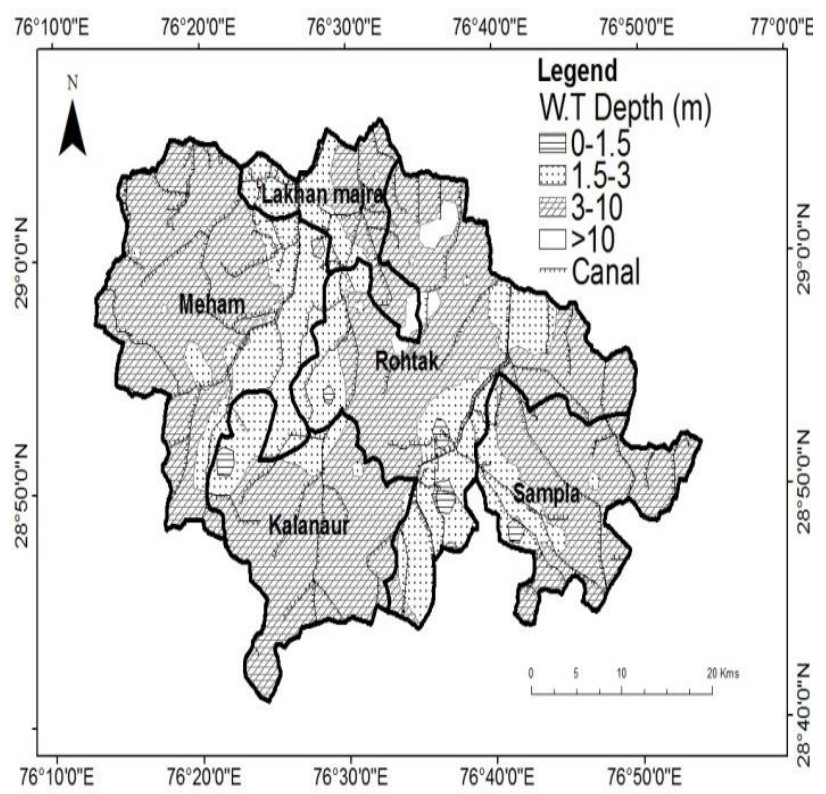

Figure. 9. Water table depth and canal network of Rohtak district

Table 7. Water table depth as a function of distance from canals

\begin{tabular}{|c|c|c|c|c|}
\hline \multirow[t]{2}{*}{ Block } & \multirow[t]{2}{*}{$\begin{array}{c}\text { Water } \\
\text { table } \\
\text { depth }(m)\end{array}$} & \multicolumn{3}{|c|}{$\begin{array}{c}\text { Area }\left(\mathbf{k m}^{2}\right) \text { within a } \\
\text { distance } \\
\text { (from canals) of }\end{array}$} \\
\hline & & $200 \mathrm{~m}$ & \begin{tabular}{|c|}
$200-500$ \\
$\mathrm{~m}$
\end{tabular} & $>500 \mathrm{~m}$ \\
\hline \multirow[t]{4}{*}{ Kalanaur } & $0-1.5$ & - & - & 3.58 \\
\hline & $1.5-3$ & 4.40 & 7.58 & 37.63 \\
\hline & $3-10$ & 23.42 & 34.30 & 184.68 \\
\hline & $>10$ & - & - & - \\
\hline \multirow{4}{*}{$\begin{array}{c}\text { Lakhan } \\
\text { Majra }\end{array}$} & $0-1.5$ & 0.28 & 0.05 & - \\
\hline & $1.5-3$ & 12.00 & 14.49 & 29.33 \\
\hline & $3-10$ & 14.60 & 19.21 & 37.26 \\
\hline & $>10$ & - & 0.01 & 5.25 \\
\hline \multirow[t]{4}{*}{ Meham } & $0-1.5$ & - & - & - \\
\hline & $1.5-3$ & 23.99 & 31.89 & 79.39 \\
\hline & $3-10$ & 42.79 & 61.80 & 221.69 \\
\hline & $>10$ & - & - & 0.41 \\
\hline \multirow[t]{4}{*}{ Rohtak } & $0-1.5$ & 2.73 & 2.98 & 4.56 \\
\hline & $1.5-3$ & 33.85 & 42.89 & 110.89 \\
\hline & $3-10$ & 35.32 & 52.40 & 231.90 \\
\hline & $>10$ & 1.57 & 3.40 & 12.27 \\
\hline \multirow[t]{4}{*}{ Sampla } & $0-1.5$ & 0.57 & 0.65 & 1.44 \\
\hline & $1.5-3$ & 9.82 & 12.65 & 26.35 \\
\hline & $3-10$ & 28.40 & 41.48 & 126.62 \\
\hline & $>10$ & - & - & - \\
\hline
\end{tabular}

The water table depths with respect to the canal network are shown in Fig. 9. The area under different 
water table depths at different distance from the canal network is given in Table 6 .

An examination of the information given in Table 7 shows that only a fraction of the area within a distance of $200 \mathrm{~m}$ from canals is under shallow water table depth $(<1.5 \mathrm{~m})$. Mere absence of shallow water table depth near canals dose not means that there is no serious loss (seepage) of water from the canal irrigation system. Groundwater pumping through farmers tubewell located near the canals may be responsible for the fact that there is not much subsurface waterlogging problem near the canals.

The surface waterlogged areas with respect to the road network are shown in Fig. 10. The surface waterlogged area at different distance from the road network is given in Table 8 .

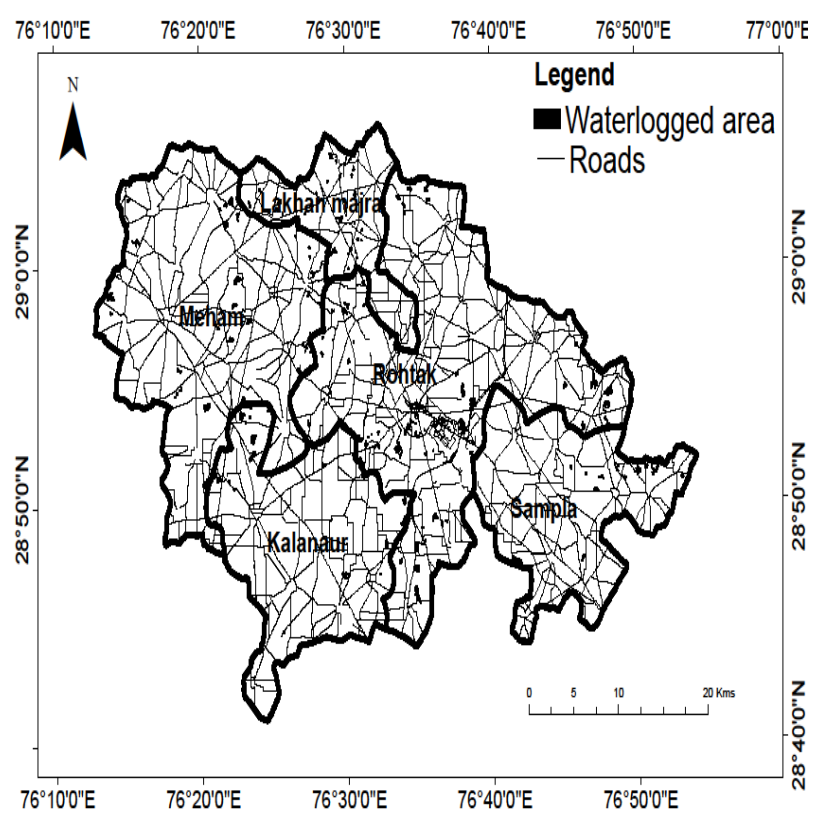

Figure. 10. Surface waterlogged area with respect to road network in the study area

Table 8. Surface waterlogged area (ha) as a function of distance from road network

\begin{tabular}{|c|c|c|c|c|}
\hline \multirow{2}{*}{ Block } & \multirow{2}{*}{$\begin{array}{c}\text { Surface } \\
\text { waterlogged } \\
\text { area }\end{array}$} & \multicolumn{2}{|c|}{$\begin{array}{l}\text { Waterlogged area within a } \\
\text { distance (from roads) of }\end{array}$} \\
\cline { 3 - 5 } & 235 & 92 & 79 & 64 \\
\hline Kalanaur & $\mathbf{2 0 0}$ m & $\mathbf{2 0 0 - 5 0 0}$ & $>\mathbf{5 0 0}$ m \\
\hline Lakhan Majra & 151 & 58 & 73 & 20 \\
\hline Meham & 403 & 132 & 145 & 126 \\
\hline Rohtak & 699 & 263 & 235 & 201 \\
\hline Sampla & 184 & 74 & 86 & 24 \\
\hline
\end{tabular}

The study area has a relatively dense network of roads. As a consequence, about 73, 87, 69, 71 and 87 percent of the surface waterlogged area in Kalanaur, Lakhan Majra, Meham, Rohtak and Sampla block, respectively, is located within a distance of $500 \mathrm{~m}$ from the roads (Fig. 11).
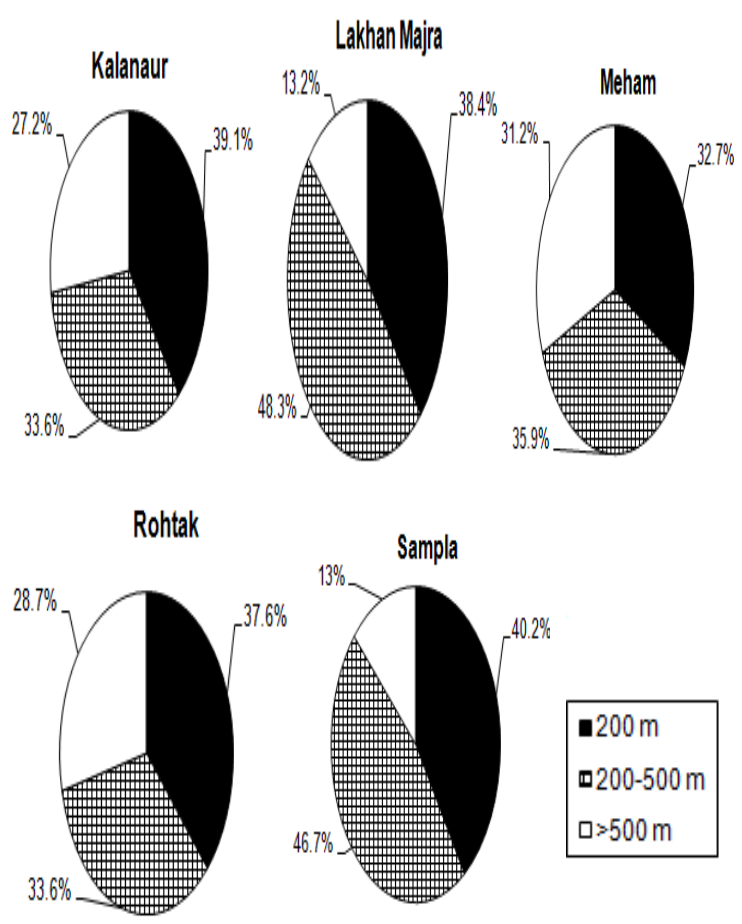

Figure. 11. Surface waterlogged area at different distances from roads in different blocks of Rohtak district

Likewise, about 39, 38, 33, 38 and 40 percent of the surface waterlogged area in Kalanaur, Lakhan Majra, Meham, Rohtak and Sampla block, respectively, is located within a distance of $200 \mathrm{~m}$ from the roads. Therefore, systematic plantation and maintenance of highly water transpiring trees (e.g. eucalyptus) along the roads could be used to partly remove the excess water.

The surface waterlogged areas with respect to the drainage network are shown in Fig.12. The surface waterlogged area at different distance from the drains is given in Table 9. 


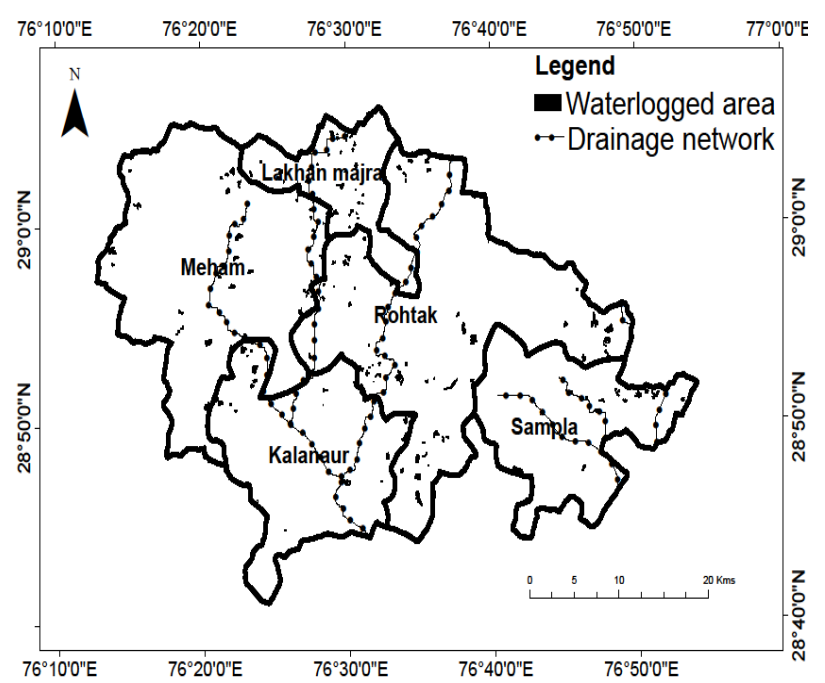

Figure. 12. Waterlogged area and drainage network of Rohtak district

The study area has limited number of surface drains. About 7, 17, 10, 3 and 11 percent of the surface waterlogged area in Kalanaur, Lakhan Majra, Meham, Rohtak and Sampla block, respectively, is located within a distance of $500 \mathrm{~m}$ from the surface drains. Likewise, about 5, 3, 5, 0.2 and 10 percent of the surface waterlogged area in Kalanaur, Lakhan Majra, Meham, Rohtak and Sampla block in fig 13 respectively, is located within a distance of $200 \mathrm{~m}$ from the surface drains.

The water table depths with respect to the drainage network are shown in Fig. 14. The area under different water table depths at different distance from the drainage network is given in Table 10.

Table 9. Surface waterlogged area (ha) as a function of distance from drains

\begin{tabular}{|c|c|c|c|c|}
\hline Block & $\begin{array}{c}\text { Surface } \\
\text { waterlogged area }\end{array}$ & \multicolumn{3}{|c|}{$\begin{array}{c}\text { Surface waterlogged area } \\
\text { within a distance (from } \\
\text { drain) of }\end{array}$} \\
\cline { 3 - 5 } & & $\mathbf{2 0 0} \mathbf{~ m}$ & $\begin{array}{c}\mathbf{2 0 0 - 5 0 0} \\
\text { m }\end{array}$ & $>\mathbf{5 0 0} \mathbf{~ m}$ \\
\hline Kalanaur & 235 & 11 & 7 & 217 \\
\hline Lakhan Majra & 151 & 5 & 21 & 125 \\
\hline Meham & 403 & 21 & 23 & 359 \\
\hline Rohtak & 699 & 2 & 19 & 678 \\
\hline Sampla & 184 & 19 & 3 & 162 \\
\hline
\end{tabular}

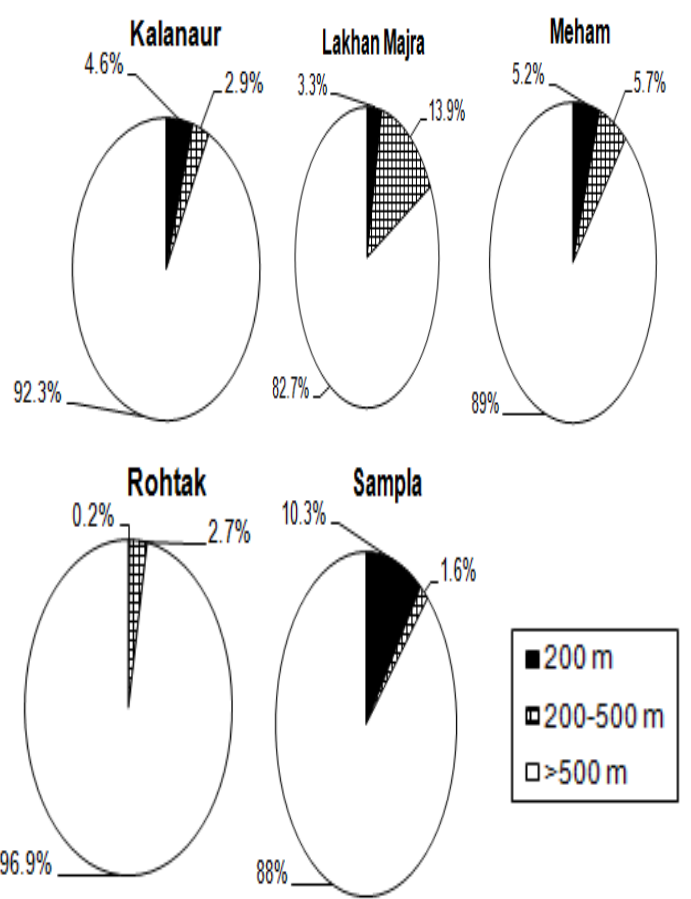

Figure.13. Surface waterlogged area at different distances from surface drains in different blocks of Rohtak district

Table 10. Water table depth as a function of distance from surface drains

\begin{tabular}{|c|c|c|c|c|}
\hline \multirow[t]{2}{*}{ Block } & \multirow[t]{2}{*}{$\begin{array}{c}\text { Water table } \\
\text { depth }(\mathrm{m})\end{array}$} & \multicolumn{3}{|c|}{$\begin{array}{c}\text { Area }\left(\mathrm{km}^{2}\right) \text { within a } \\
\text { distance (from surface } \\
\text { drains) of }\end{array}$} \\
\hline & & $200 \mathrm{~m}$ & $\begin{array}{c}200-500 \\
\mathrm{~m}\end{array}$ & $>500 \mathrm{~m}$ \\
\hline \multirow[t]{4}{*}{ Kalanaur } & $0-1.5$ & - & - & 3.58 \\
\hline & $1.5-3$ & 3.30 & 4.78 & 41.53 \\
\hline & $3-10$ & 12.78 & 17.62 & 212.00 \\
\hline & $>10$ & - & - & - \\
\hline \multirow{4}{*}{$\begin{array}{l}\text { Lakhan } \\
\text { Majra }\end{array}$} & $0-1.5$ & - & - & 0.33 \\
\hline & $1.5-3$ & 3.32 & 4.63 & 47.87 \\
\hline & $3-10$ & 1.01 & 1.81 & 68.25 \\
\hline & $>10$ & 1.62 & 1.99 & 1.65 \\
\hline \multirow[t]{4}{*}{ Meham } & $0-1.5$ & - & - & - \\
\hline & $1.5-3$ & 4.74 & 7.97 & 122.56 \\
\hline & $3-10$ & 7.73 & 10.71 & 307.84 \\
\hline & $>10$ & - & - & 0.41 \\
\hline \multirow[t]{4}{*}{ Rohtak } & $0-1.5$ & - & 0.02 & 10.25 \\
\hline & $1.5-3$ & 3.59 & 5.16 & 178.88 \\
\hline & $3-10$ & 9.29 & 13.41 & 296.92 \\
\hline & $>10$ & 1.99 & 3.32 & 11.93 \\
\hline \multirow[t]{4}{*}{ Sampla } & $0-1.5$ & - & - & 2.66 \\
\hline & $1.5-3$ & 0.77 & 1.34 & 46.71 \\
\hline & $3-10$ & 12.62 & 18.85 & 165.03 \\
\hline & $>10$ & - & - & - \\
\hline
\end{tabular}




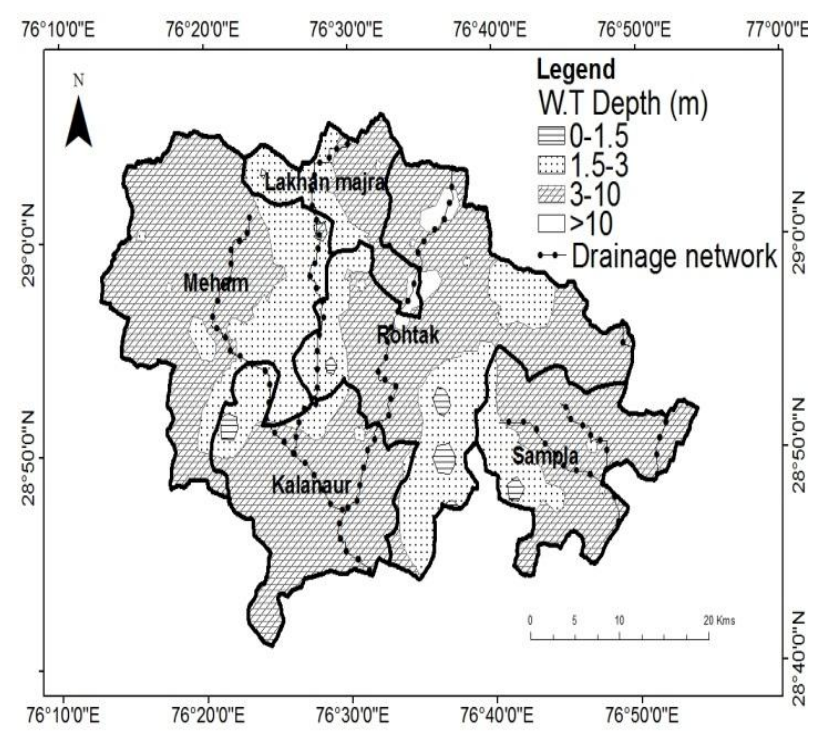

Figure. 14. Water table depth and drainage network of Rohtak district

There is negligible area under shallow water table depth $(<1.5 \mathrm{~m}$, Table 10) within a distance of $500 \mathrm{~m}$ from the surface drains. Two important observations can be made at this point. Surface drains are quite effective in controlling both surface and subsurface waterlogging problems in the vicinity of the drains. It is important to note that the surface waterlogging situation being discussed was for the pre monsoon period thereby meaning that surface water stagnation is present near the drains as well. Therefore, there is need to construct/strengthen the field scale surface drainage system with suitable outlets to the existing surface drains.

\section{Ground water quality (EC) and water table depth}

The electrical conductivity $(\mathrm{EC})$ of groundwater in the study area varied from 0.4 to $9.3 \mathrm{dS} \mathrm{m}^{-1}$. The groundwater quality is generally good (EC $\left.0-2 \mathrm{dS} \mathrm{m}^{-1}\right)$ in the central part of the district. It is important to note that the groundwater quality map (Fig. 15) is based on samples collected from the existing tubewells at the farmer's fields and therefore, may not necessarily reflect the quality of shallow groundwater. The area under different groundwater quality ranges in the study area is given in Table 11.

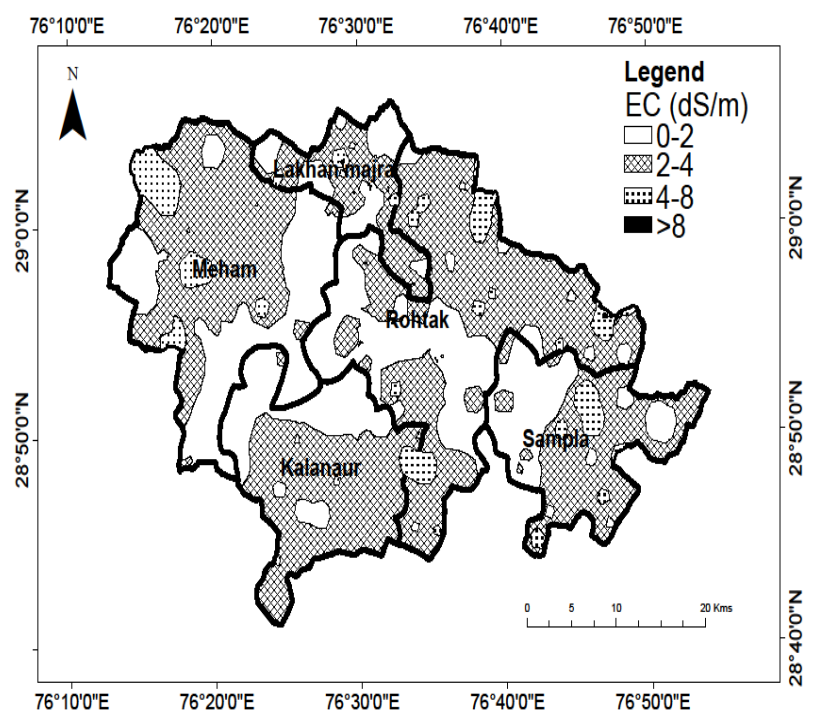

Figure. 15. Groundwater quality (EC) map of study area

Table 11. Area $\left(\mathrm{km}^{2}\right)$ under different classes of groundwater quality in the study area

\begin{tabular}{|c|c|c|c|c|}
\hline \multirow{2}{*}{ Block } & \multicolumn{4}{|c|}{ Electrical conductivity, EC, dS m } \\
& $\mathbf{0 - 2}$ & $\mathbf{2 - 4}$ & $\mathbf{4 - 8}$ & $>\mathbf{8}$ \\
\cline { 2 - 5 } & & & & \\
\hline Kalanaur & 98.82 & 192.72 & 4.05 & - \\
\hline Lakhan Majra & 51.86 & 75.96 & 4.48 & 0.17 \\
\hline Meham & 184.26 & 239.82 & 37.86 & - \\
\hline Rohtak & 171.34 & 331.90 & 31.26 & 0.25 \\
\hline Sampla & 89.46 & 140.68 & 17.85 & - \\
\hline Rohtak district & 595.74 & 981.08 & 95.50 & 0.42 \\
\hline
\end{tabular}

The overlaying of groundwater quality map and water table depth map resulted into thirteen different combination (Fig. 16) of groundwater quality and water table depth (Table 12) in the study area.

Table 12. Area $\left(\mathrm{km}^{2}\right)$ under different combination of groundwater quality and water table depth in Rohtak district

\begin{tabular}{|c|c|c|c|}
\hline $\begin{array}{c}\text { Zonation } \\
\text { No. }\end{array}$ & \begin{tabular}{|c|} 
Groundwater \\
quality $\left(\mathrm{dS} \mathrm{m}^{-1}\right)$
\end{tabular} & \begin{tabular}{|c|} 
Water \\
table \\
depth $(m)$
\end{tabular} & $\begin{array}{l}\text { Area } \\
\left(\mathbf{k m}^{2}\right)\end{array}$ \\
\hline Zone 1 & $0-2$ & $0-1.5$ & 13.65 \\
\hline Zone 2 & $0-2$ & $1.5-3$ & 293.36 \\
\hline Zone 3 & $0-2$ & $3-10$ & 284.82 \\
\hline Zone 4 & $0-2$ & $>10$ & 3.91 \\
\hline Zone 5 & $2-4$ & $0-1.5$ & 3.20 \\
\hline Zone 6 & $2-4$ & $1.5-3$ & 170.52 \\
\hline Zone 7 & $2-4$ & $3-10$ & 788.49 \\
\hline Zone 8 & $2-4$ & $>10$ & 18.96 \\
\hline Zone 9 & $4-8$ & $1.5-3$ & 13.11 \\
\hline Zone 10 & $4-8$ & $3-10$ & 82.39 \\
\hline
\end{tabular}




\begin{tabular}{|c|c|c|c|}
\hline Zone 11 & $4-8$ & $>10$ & 0.03 \\
\hline Zone 12 & $>8$ & $1.5-3$ & 0.15 \\
\hline Zone 13 & $>8$ & $3-10$ & 0.27 \\
\hline
\end{tabular}

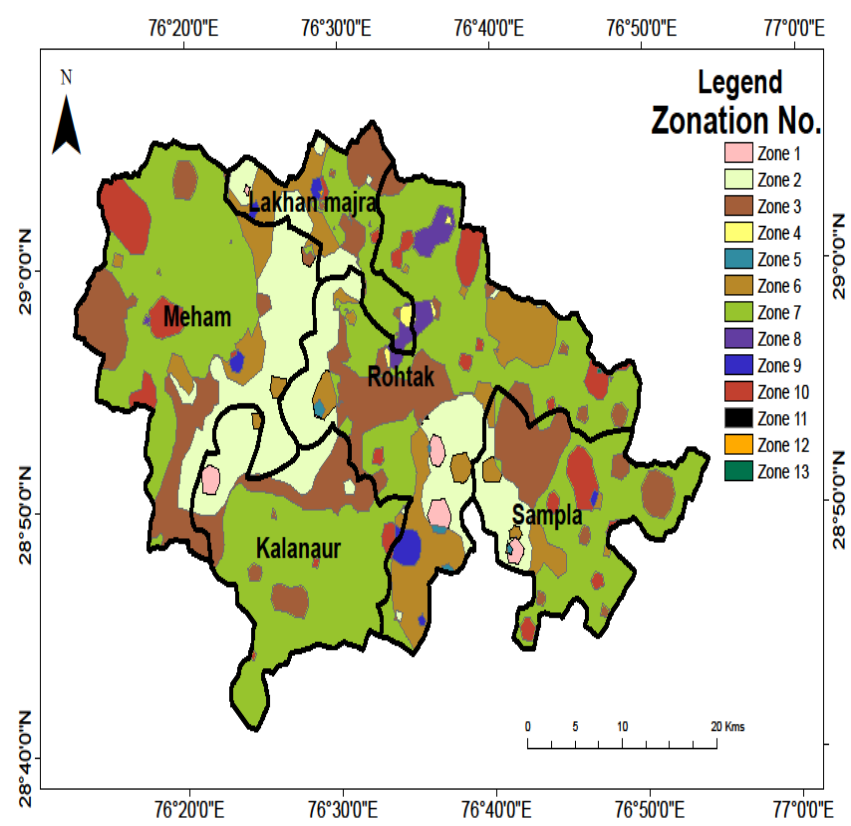

Figure. 16. Groundwater quality and water table depth of Rohtak district

\section{Management strategies for waterlogged areas}

As noted earlier, the study area is faced with surface waterlogging (Fig. 1) as well as subsurface waterlogging (Fig.3) conditions and is underlain with shallow water table, part of which is also saline in nature. No natural drain passes through the study area and a limited number of artificial surface drains have been constructed due to inland drainage basin conditions of the area. Moreover, the transport and canal network in the study area often creates locally impeded drainage conditions. It is, thus, clear that the management of waterlogging conditions in the study area is quite complex. Considering the spatially variable nature of the hydrological conditions in the study area, a number of strategies have to be implemented for the management of waterlogged areas.

\section{Management strategies for surface waterlogged areas}

(a) The excess surface water stagnating within a distance of $500 \mathrm{~m}$ from canals (particularly in Lakhan Majra and Meham block) may be collected in suitably located sump wells near the canals for its subsequent pumping in to the canals thereby augmenting the canal water supply.

(b)The excess surface water stagnating beyond 500 $\mathrm{m}$ from canals, may be collected in specially designed water harvesting tanks for its subsequent utilization agriculture/fish production.

(c)The excess surface water stagnating within a distance of $500 \mathrm{~m}$ from existing drains need to be directed into the drains by constructing/strengthening the field scale surface drainage system.

(d) Public lands along the roads may be utilized to grow highly water transpiring trees (e.g. eucalyptus).

(e)The surface waterlogging condition usually worsen during rainy season, therefore, there is need to strengthen the existing network of surface drains.

Management strategies for sub-surface waterlogged areas

The study area was divided into different zones (Fig. 16) with different combinations of water table depth $\left(D_{g w}\right)$ and groundwater quality $\left(E C_{g w}\right)$. The suggested strategies for the identified zone are described in this section. Zone 4, Zone 8 and Zone 11 (Table 12) are safe (water table depth $>10 \mathrm{~m}$ ) from subsurface waterlogging risks and Zone 12 and Zone 13 together accounts for only about $0.02 \%$ of the study area. Accordingly Zone 4 , $8,11,12$ and 13 are not included in the subsequent discussion.

Zone $1\left(E C_{g w}=0-2 d S m^{-1}, D_{g w}=0-1.5 \mathrm{~m}\right)$ : The area under this zone is about $0.81 \%$ of the total area of the district. Water table is quite shallow and a small recharge amount would be sufficient to bring the water table to surface. Therefore, there is need to have a strong surface drainage system coupled with efficient irrigation system (such as sprinkler irrigation). Surface drainage system and enhanced use of groundwater shall help to lower the water table beyond crop root zone.

Zone $2\left(E C_{g w}=0-2 d S m^{-1}, D_{g w}=1.5-3.0 \mathrm{~m}\right)$ : The area under this zone is about $17.53 \%$ of the total area of the district. Water table is susceptible to rise into the root zone during rainy season. Conjunctive use of canal water (reduced) and groundwater and effective surface drainage would help to avoid the risk of water table being in the root zone.

Zone $3\left(E C_{g w}=0-2 d S m^{-1}, D_{g w}=3 \cdot 0-10.0 \mathrm{~m}\right)$ : The area under this zone is about $17.02 \%$ of the total area of the district. Surface drainage coupled with efficient on farm irrigation water management is needed to keep the water table within safe limits. 
Zone $5\left(E C_{g w}=2-4 d S m^{-1}, D_{g w}=0-1.5 \mathrm{~m}\right)$ : The area under this zone is about $0.23 \%$ of the total area of the district. Rainwater harvesting followed by the use of stored water in conjunction with groundwater for semi (salt) tolerant crops (e.g. sorghum and maize) is to be adopted. Ideally, such conditions would demand the installation of subsurface drainage system. However, considering the small aerial extent, it is suggested to exploit the potential of deep rooted, highly transpiring trees to keep the water table beyond crop root zone. Since water table is very shallow, trees have to be planted on raised ( $0.5 \mathrm{~m}$ height) ridges [14].

Zone $6\left(E C_{g w}=2-4 d S m^{-1}, D_{g w}=1.5-3.0 \mathrm{~m}\right)$ : The area under this zone is about $10.19 \%$ of the total area of the district. Conjunctive use of groundwater and stored rainwater, adoption of semi (salt) tolerant crops in the cropping pattern, plantation of deep rooted and highly transpiring trees, planned leaching of salts and increased irrigation efficiency are some of the strategies to be adopted.

Zone $7\left(E C_{g w}=2-4 d S m^{-1}, D_{g w}=3.0-10.0 \mathrm{~m}\right):$ This zone occupies the largest area in the district i.e. $47.13 \%$ of the total area of the district. Conjunctive use of groundwater and stored rainwater, adoption of semi (salt) tolerant crops in the cropping pattern, planned leaching of salts and increased irrigation efficiency are the strategies to be adopted.

Zone $9\left(E C_{g w}=4-8 d S m^{-1}, D_{g w}=1.5-3.0 \mathrm{~m}\right)$ : The area under this zone is about $0.78 \%$ of the total area of the district. Conjunctive use of groundwater and stored rainwater, adoption of salt tolerant crops (e.g. wheat and cotton) in the cropping pattern, planned leaching of salts and increased irrigation efficiency are the strategies to be adopted. Besides these, part of the groundwater pumped may be stored in ponds for fish production.

Zone $10\left(E C_{g w}=4-8 d S m^{-1}, D_{g w}=3.0-10.0 \mathrm{~m}\right)$ : The area under this zone is about $4.92 \%$ of the total area of the district. Strategies similar to zone 9 may also be adopted for this zone.

\section{IV.CONCLUDING REMARKS}

Based on satellite imagery, about one per cent of the study area was found to be affected by surface waterlogging during the pre-monsoon period of 2010. The maximum surface water logging problem was encountered in the Rohtak block of the study area. Based on water table depth maps, about one per cent of the study area having water table depth shallower than $1.5 \mathrm{~m}$ while about 28 per cent of the study area was having water table depth of 1.5 to $3.0 \mathrm{~m}$. Based on the groundwater quality map, about 35.6 per cent of the study area was underlain with groundwater of less than $2 \mathrm{dS} \mathrm{m}$ 1 , while about $58.7 \%$ of the area was underlain with groundwater having EC between 2-4 $\mathrm{dS} \mathrm{m}^{-1}$. In order to identify suitable strategies for the management of shallow water table conditions, the whole of the study area was divided into different zones with uniformity with respect to water table depth and water quality.

Based on different thematic maps, data analysis and interpretation, complete and accurate quantification of surface waterlogged areas through visual inspection of satellite imagery (FCC) may not be possible. Digital image processing supported by intensive ground truth observations should be evaluated for effective use of satellite remote sensing to assess waterlogged areas. The network of observations wells for the monitoring of water table depths need to be strengthened in the study area to capture the true picture of spatio-temporal variability of groundwater levels. The identified standard strategies includes: surface drainage system, efficient irrigation system, reduction in canal water supply, conjunctive use of canal water, groundwater and rainwater, introduction of salt tolerant crops, plantation of highly transpiring trees, planned leaching of salts and fish farming with saline water.

\section{REFERENCES}

[1].Ahmed, N. \& Chaudhary, G.R., 1988, Irrigated Agriculture of Pakistan. Shahzad Nazir Publications, Lahore.

[2].Choubey, V.K., 1996, Assessment of waterlogged area in IGNP Stage I by remotely sensed and field data. Hydrology Journal, 19 (2), pp. 81-93.

[3].Lohani, A.K., Jaiswal, R.K. \& Jha, R., 1999, Waterlogged area mapping of Mokama group of Tals using remote sensing and GIS. Journal of Institution of Engineers, 80(1), pp. 133-137.

[4].Mehta, M., 2000, Waterlogging in India. Bhu-Jal News, 15(1\&2), pp. 35-38.

[5].Sidhu, P.S., Sharma, P.K. \& Bajwa, M.S., 1991, Characteristics, distribution and genesis of salt affected soils in Punjab. Journal of the Indian society of Remote sensing, 19 (4), pp. 269-276.

[6].Choubey, V.K., 1997, Detection and delineation of waterlogging by remote sensing techniques. Journal of the Indian Society of Remote Sensing. 25(2), pp. 123-135.

[7].Ray, S.S., Dadhwal, V.K. \& Navalgund, R.R., 2002, Performance evaluation of an irrigation command area using remote sensing: a 
case study of Mahi command, Gujarat, India. Agricultural Water Management, 56, pp. 81-91.

[8].Belford, R.K., \& McFarlane, D.J., 1993, Managing water logging and inundation in pastures. Western Australian Department of Agriculture, Farmnote No. 79/93, South Perth, WA, 4.

[9].Sharma, P.K., Chopra, R., Verma, V.K. \& Thomas, A., 1996, Flood management using remote sensing technology: the Punjab (India) experience. International Journal of Remote Sensing, 17(17), pp. 3511-3521.

[10].Thomsen, R., Sondergaard, V.H. \& Sorensen, K.I., 2004, Hydrogeological mapping as a basis for establishing sitespecific groundwater protection zones in Denmark. Hydrogeology Journal, 12(5), pp. 550-563.

[11].Shakya, S.K. \& Singh, J.P., 2010, New drainage technologies for salt-affected waterlogged areas of southwest Punjab. India. Current Science, 99( 2), pp. 204.
[12].Manju, G., Chowdhary, V.M., Srivastava, Y.K., Selvamani, S., Jeyaram, A. \& Adiga, S., 2005, Mapping and characterization of inland wetlands using Remote sensing and GIS. Journal of the Indian Society of Remote Sensing, 33(1), pp. 51-61.

[13].Chaudhary, B.S. \& Aggarwal, S., 2009, Demarcation of palaeochannels and integrated ground water resources mapping in parts of Hisar District, Haryana. Journal of the Indian Society of Remote Sensing, 37, pp. 251-260.

[14].Ram, J., Dagar, J.C., Lal, K., Singh, G., Toky, O.P., Tanvar, V.S., Dar, S.R. \& Chauhan, M.K., 2011, Biodrainage to combat waterlogging, increase farm productivity and sequester carbon in canal command areas of north west India. Current Science, 100(11), pp. 1673-1680. 